\title{
Chapter 5. Russet- Skinned Fresh Market Potato Variety Trial, 20061
}

\section{C.M. Hutchinson and Doug Gergela ${ }^{2}$}

General Comments: A goal of the Russet-Skinned Fresh Market Potato Variety trial is to identify a short-season russet skinned variety that produces a marketable crop under short-day production. Successful russet varieties could be grown for processing or for the fresh market. There is no current standard for North Florida production.

Planting Information

\begin{tabular}{|l|l|}
\hline Planting Site & PSREU - Hastings Farm, Hastings, FL \\
\hline Planting Date & January 31, 2006 \\
\hline Vine Kill Date & April 28, 2006 \\
\hline Harvest Date & May 30, 2006 \\
\hline Season Length & 87 days planting to vine kill; 119 days planting to harvest \\
\hline Fertilizer Program & preplant, 100-43-86 lb/A; sidedress, 65-0-56 lb/A; (2 appl.) \\
\hline Irrigation Program & seepage \\
\hline
\end{tabular}

\section{Experimental Design}

\begin{tabular}{|l|l|}
\hline Experimental Design & 7 (Standard: Goldrush) \\
\hline Number of Varieties & 1 \\
\hline Number of Clones & 8 in $(20 \mathrm{~cm})$ \\
\hline Within Row Spacing & 40 in $(102 \mathrm{~cm})$ \\
\hline Between Row Spacing & 4 \\
\hline Replications & $16 \mathrm{ft}(4.9 \mathrm{~m})$ \\
\hline Plot Size &
\end{tabular}

\section{Production Statistics}

\begin{tabular}{|l|l|}
\hline Early Vigor Ratings & 41 days after planting \\
\hline Highest Total Yield & Goldrush $(331 \mathrm{cwt} /$ acre or $37.1 \mathrm{MT} / \mathrm{ha})$ \\
\hline Highest Marketable Yield & Goldrush (223 cwt/acre or 25.0 MT/ha) \\
\hline Best Appearance Rating & Goldrush, Amey, Belrus and Ranger Russet (7.0, good to excellent) \\
\hline
\end{tabular}

1. This document is HS1090, one of a series of the Horticultural Sciences Department, Florida Cooperative Extension Service, Institute of Food and Agricultural Sciences, University of Florida. Original publication date June, 2007. Visit the EDIS Web Site at http://edis.ifas.ufl.edu.

2. Chad M. Hutchinson, Associate Professor, Doug Gergela, Sr. Biological Scientist, Horticultural Sciences Department, Cooperative Extension Service, Institute of Food and Agricultural Sciences, University of Florida, Gainesville, 32611.

The use of trade names in this publication is solely for the purpose of providing specific information. UF/IFAS does not guarantee or warranty the products named, and references to them in this publication do not signify our approval to the exclusion of other products of suitable composition. All chemicals should be used in accordance with directions on the manufacturer's label. Use pesticides safely. Read and follow directions on the manufacturer's label.

The Institute of Food and Agricultural Sciences (IFAS) is an Equal Opportunity Institution authorized to provide research, educational information and other services only to individuals and institutions that function with non-discrimination with respect to race, creed, color, religion, age, disability, sex, sexual orientation, marital status, national origin, political opinions or affiliations. U.S. Department of Agriculture, Cooperative Extension Service, University of Florida, IFAS, Florida A. \& M. University Cooperative Extension Program, and Boards of County Commissioners Cooperating. Larry Arrington, Dean 


$$
\text { 渭间 }
$$




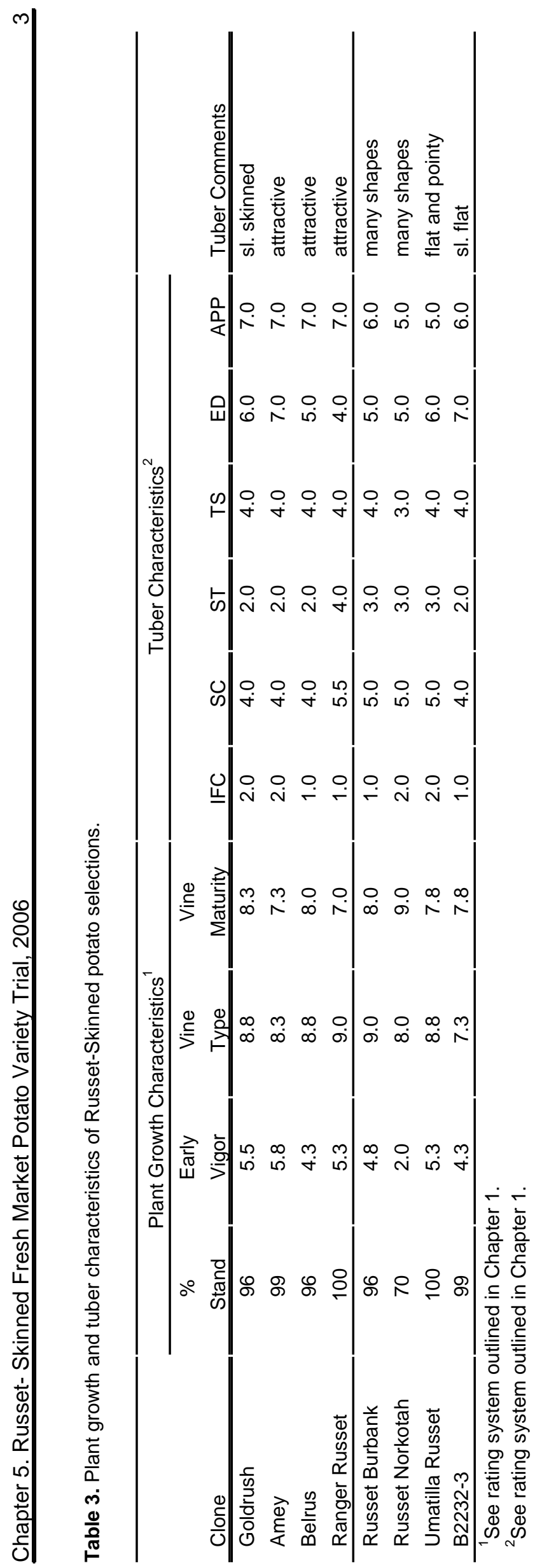




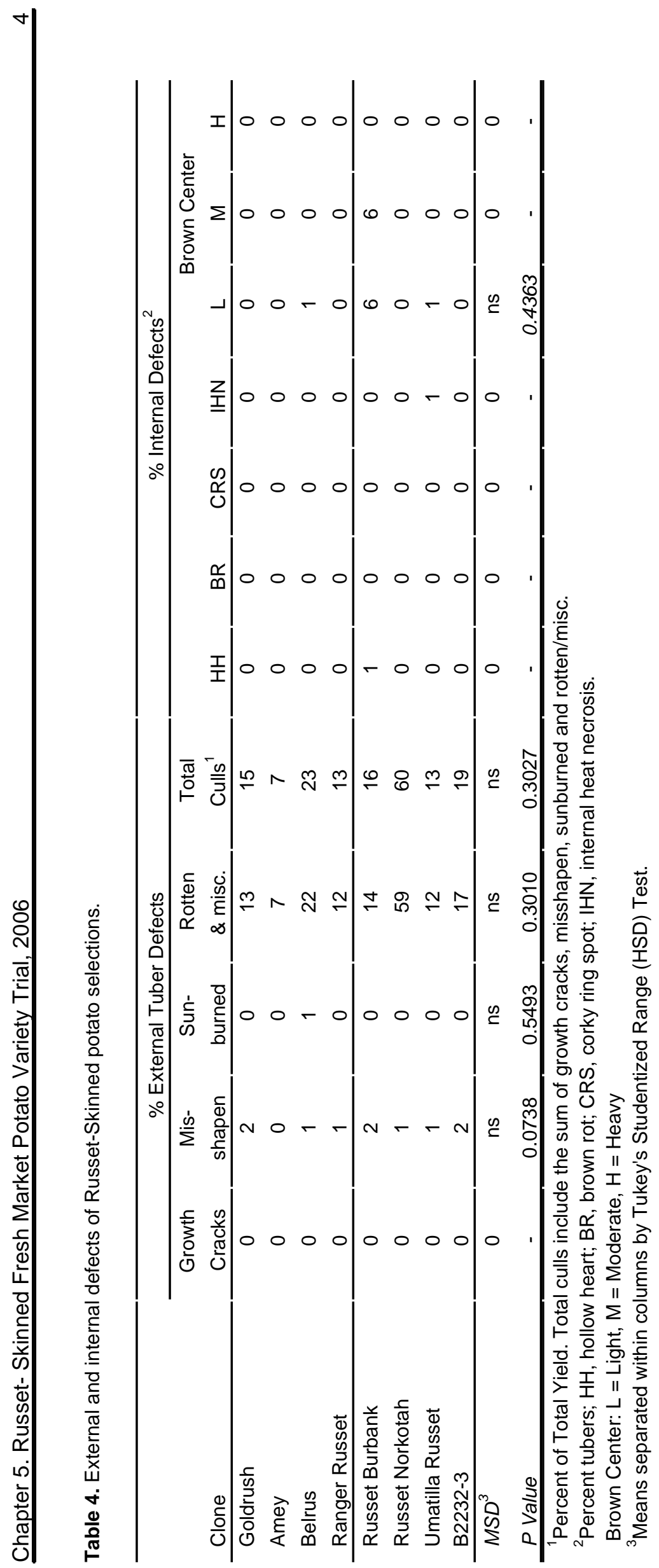

